\title{
THE SOCIAL DEMOGRATIC POPULIST PARTY: REVISITING THE RECENT PAST OF SOCIAL DEMOCRACY IN TURKEY
}

\author{
Uğur Tekiner \\ Cambridge Üniversitesi \\ Siyaset ve Uluslararası Çalışmalar Bölümü \\ Doktora Öğrencisi \\ ORCID: 0000-0002-7478-3891
}

\begin{abstract}
This study aims to examine the case of the Social Democratic Populist Party (Sosyaldemokrat Halkçı Parti - SHP) that functioned as the major representative of the social democratic ideology in Turkey under highly extraordinary conditions of the post-1980 coup political atmosphere until 1995 . Realizing the necessity of taking this critically important phase in the evolution of Turkish social democratic thought into account, the major argument of this paper is that even if the SHP spent a remarkable amount of effort for achieving its ultimate target of evolving into a European-style, 'genuine' social democratic party, it ultimately failed to reach this end due to three interrelated factors, such as changing political realities in the domestic and European contexts during the 1980s, the intra-party turmoil within the SHP, and the poor performance of the SHP in power. In relation to this core argument, the ideological decline of the SHP is claimed to have a direct impact on the successive electoral defeats and ideological drifts of the CHP, as its successor, in the following years.

Keywords: Turkish social democracy, Centre left, The Social Democratic Populist Party, The
\end{abstract} Republican People's Party, Post-1980 Turkish politics

Sosyaldemokrat Halkçı Parti: Türkiye'de Sosyal Demokrasinin Yakın Geçmişi Üzerine Yeniden Düşünmek

\section{Öz}

Bu çalışma, 1980 darbesi sonrası siyasi atmosferin hayli olağanüstü koşulları altında, Türkiye'de sosyal demokrat ideolojinin başlıca temsilcisi olarak ortaya çıkan ve 1995 'e kadar varlığını sürdüren Sosyaldemokrat Halkçı Parti (SHP) vakasını incelemeyi amaçlamaktadır. Türkiye'deki sosyal demokrat düşüncenin evriminde kritik önem taşıyan bu safhayı dikkate almanın gerekliliğinin bilincinde olan bu makalenin temel savı, SHP'nin, nihai amacı olan, Avrupa tipi, 'gerçek' bir sosyal demokrat parti haline gelebilmek için hatırı sayılır bir çaba harcadığı halde, 1980li yıllarda Avrupa'da ve Türkiye'de değişen siyasi ortam, SHP içindeki parti içi kargaşa ve SHP'nin iktidardaki düşük performansı gibi birbiriyle bağlantılı üç etken nedeniyle son kertede bu amacına ulaşmada başarısız olduğudur. Bu temel savla bağlantılı olarak, SHP'nin ideolojik açıdan gerilemesinin, SHP'nin halefi olan CHP'nin sonraki yıllarda art arda gelen seçim yenilgilerine ve ideolojik kaymalarına doğrudan etkisi olduğu iddia edilmektedir.

Anahtar Sözcükler: Türk sosyal demokrasisi, Merkez sol, Sosyaldemokrat Halkçı Parti, Cumhuriyet Halk Partisi, 1980 sonrası Türkiye siyaseti

* Makale geliş tarihi: 01.02.2018

Makale kabul tarihi: 23.07.2018

Erken görünüm tarihi: 05.07.2019 


\section{The Social Democratic Populist Party': Revisiting the Recent Past of Social Democracy in Turkey*}

\section{Introduction}

Today, almost everyone is talking about the existential crisis that European social democracy has undergone in the last few decades. For some comments, it is even possible to simply talk about the downfall or death of social democracy in Europe (Karnitschnig, 2018). Given the ongoing internal divisions, shrinking support bases, and declining electoral performances of social democratic parties in Europe, it does not seem hard to estimate that all this lively debate on the current retreat of social democracy is likely to flourish. Despite appearing to be a phenomenon of recent times, the multifaceted crisis of European social democracy is possible to be traced to as early as the early-1970s.

As the post-war consensus, led by social democrats, reached an end and the welfare state model, emerging as the concrete output of the social democratic ideology in the post-war period, started to malfunction, the European social democratic parties found themselves in an escalating crisis. As this crisis bore many crucial consequences not possible to be ignored, the decade of the 1980s proved to be extremely tough for these parties.

1 Although there exists an obvious confusion in the related literature over the use of the term, 'People's Party' or 'Populist Party' in order to define the SHP of 1985-1995, the 'Social Democratic Populist Party' as a name has been intentionally used for this party throughout this article in order to underline its difference from the 'Social Democratic People's Party (Sosyaldemokrat Halk Partisi)', established by the former SHP politicians in 2002.

* I would like to thank Prof. Dr. Ayşe Ayata, for all her guiding comments, and Prof. Dr. Necmi Erdoğan, for providing me with the reading materials that have been a great help in writing this article, and two anonymous reviewers, whose reviews have contributed a great deal to the reshaping of this study 
Likewise, during the same period, the situation of the social democratic ideology in Turkey, flourishing under the indispensable impact of the debates taking place on European social democracy, was not that different. Alongside the effect of the ideological, electoral and political decay of social democracy in the European continent, Turkish social democracy was also deeply challenged by domestic occurrences. In particular, when the military takeover of 12 September $1980^{2}$ dissolved all the political parties including the Republican People's Party (Cumhuriyet Halk Partisi-CHP) ${ }^{3}$, this turned out to be a harsh blow for Turkish social democracy, already becoming one of the permanent political movements in the Turkish context, as proven by its ideological, organisational, and political strength. As the National Security Committee (MGK) -the military junta led by Kenan Evren- embarked on a comprehensive transformation in the deeply polarised and conflict-ridden political party system, it did not abstain from practising rigid prohibitions on the CHP politicians, like the politicians of other parties. In such a restricted political climate, the Social Democracy Party (SODEP) -not permitted to participate in the 1983 elections-, and the Populist Party (HP) -allowed to compete in these elections by the military regimeemerged claiming for the notable political legacy of the banned CHP.

As time passed, the SODEP, presided by Erdal İnönü, increasingly gained more ground than the HP as the perceived heir of the CHP in the public opinion. ${ }^{4}$ Therefore, in order to put an end to the anomaly of a parliamentary party with no popular support, as the HP, and another party enjoying electoral backing without

2 The 12 September 1980 coup d'état, headed by Kenan Evren, the Chief of General Staff, and other commanders-in-chief, is the third military takeover in the modern Turkish political history, the previous two being the 27 May 1960 coup and the 12 March 1971 Memorandum. Putting under arrest, blacklisting, and revoking the citizenship of thousands of people, the 1980 coup caused an abrupt, and unequivocally bitter, break with the recent past due to its wide-ranging intervention into the reconstruction of political, and socio-economic life. In the aftermath of the coup, the generals ruled the country for more than 3 years up until the 6 November 1983 elections, when Özal's Motherland Party (ANAP) came to power. Until the end of Kenan Evren's 'presidency', members of the military junta kept holding onto power under the formal guise of the 'Presidential Council'.

3 Established by Mustafa Kemal Atatürk, the founder and first president of the modern Republic of Turkey, and his closest allies in 1923, the CHP is primarily known to be the founding party of the Republic, alongside setting up the institutional framework of the state, leading the transition to the multi-party regime in 1946, and finally espousing a social democratic/democratic left line from mid-1960s.

4 Mango (1991, p. 171) points out that at the time of its foundation in 1983, the SODEP was described as an association of all those members of the CHP who had parted ways with its last leader, Bülent Ecevit. Given these aspects, it would not be wrong to define the party as the 'unreconstructed CHP' for the author. 
any parliamentary representation, as the SODEP, these two parties went into a merger, and the Social Democratic Populist Party -from then on the SHPappeared in the political scene by 1985 (Turan, 2006: 561). All that said, the SHP survived the turbulent political conditions of the post-1980 coup period and remained as the main representative of the social democratic ideology until 1995.

Given the necessity of enquiring the multitude of problems encountered recently by the CHP, as the party standing for the social democratic constituency in Turkey, revisiting the SHP period is of significance theoretically and practically due to two main reasons. Firstly, as a party re-opened in 1992, the CHP was actually revived, particularly on practical and organizational terms, as the successor of the SHP, rather than the pre-1980 CHP. It is true that the period covering between 1923 and 1980 continues to be the primary reference point for many party officials and supporters, but this does not disguise the fact that the current CHP came into being in 1992 as mostly settled on the political, ideological and institutional legacy of the SHP. Therefore, in making a discussion over the current problems of the party, it does not make sense to neglect the SHP period. As the second reason, it does not seem probable to thoroughly grasp the peculiar ideological and institutional development, and surely drawbacks, of Turkish social democracy by ignoring the steps taken by the SHP, back and forth, in evolving into a 'genuine' 5 social democratic party. Intended to fill the vacancy caused by the banning of the CHP from the political game by the junta, the SHP became committed to an agenda wavering between the poles of preserving the social democratic roots and adjusting to the reality of the 'new times' after a while. Therefore, making a thorough analysis of the SHP period via keeping an eye on its links with the recent crisis of Turkish social democracy in the context of the CHP constitutes the main aim of this article.

Adhered to revisiting such a critical period in the history of social democracy in Turkey, the major argument of this paper is that even if the SHP worked hard for emerging as a European-style social democratic party, it eventually failed in this end because of three interrelated factors that will be separately examined throughout this article. In line with this main argument, then, this ideological decline, exceeding the lifetime of the SHP, is considered to have an implicitly negative impact on the successive electoral defeats and ideological drifts of the CHP, the successor of the SHP, from the New Left to the Anatolian Left (Anadolu Solu) and ultimately to the adoption of a more nationalist-laicist approach during the Baykal period.

5 Since this article is not preoccupied with making an ideal definition of social democracy from a Eurocentric point of view, the term, 'genuine' will be merely used to connote the way the SHP conceived social democracy as an ideology practised in its purest and perfect form in the European context. 
In this respect, firstly, after elaborating on the divergent aspects of Turkish social democracy, the external dimension of the SHP's failure in evolving into a European-style social democratic party will be examined in terms of the drastic changes happening both in the European and domestic political settings from the early-1980s onwards. As the second underlying factor, the internal dimension of this matter will be looked at with the primary focus on the deteriorations happening in the ideological stance, organisational network and support base of the party. Finally, the low executive performance of the SHP in the local context after winning the 1989 local elections and in the general context during the True Path Party (DYP)-SHP coalition between 1991 and 1995 altogether will be scrutinised as the third factor believed to be explaining the SHP's decline in time.

\section{The Divergent Course of Social Democracy in Turkey}

A discussion on the root causes of the SHP's failure initially necessitates focusing on the distinctive progress of social democracy in Turkey, in comparison to Europe. Such a comparison, and contrast, is mostly required due to the SHP's ambitious end goal of evolving into a European-style social democratic party, defined in many party documents as the 'genuine' social democratic party structure to be adopted. Moreover, this comparison is needed because in a wide range of problems it encountered, the SHP, as a party longing for stepping into the shoes of the banned CHP, bore the trace of the authentic development of Turkish social democracy preceding its establishment. Bearing in mind the general course of European social democracy ${ }^{6}$, the divergent path of Turkish social democracy is possible to be examined based on three dimensions including ideological, organizational, and electoral ones ${ }^{7}$.

On ideological accounts, the birth and progress of social democracy in the $\mathrm{CHP}$, as the party founding the state and leading the modernization process, has always been at the centre of the disputes. In manifesting the divergent course of Turkish social democracy, mainly the structural and agency-related aspects have been underlined. Enquiring into why the Western European type of social

6 Not denoting a uniform model, European social democracy comprisees divergent tendencies feeding from the exclusive conditions of each country. In this respect, one of the main categorizations is the one dividing between North European and South European social democratic models. For another typology, the Western European social democracy is distinguished from its non-Western counterparts.

7 These three dimensions are picked on purpose with the primary intention of revealing their durable impact on the SHP's failure, argued to take place on the very same layers. 
democracy has not developed in Turkey, Emre argues that social democracy's failure in Turkey has mainly stemmed from the historical and structural constraints that obstructed social democracy, on the one side, and the wrong policy paths chosen by the leadership of these social democratic parties, such as party politics based on secularism and Turkish nationalism, on the other side (Emre, 2015: 393). Likewise, aiming to explain 'transformational failures of social democracy in Turkey' from a 'structure-agency framework', Keyman and Öniş (2007: 217) provide a twofold categorization of structural forces or processes and agency-related problems. In the first category, together with the underdeveloped nature of the welfare state and the unionized labour force in Turkey and the effect of the worldwide neoliberal restructuring and globalization, they make the primary emphasis on the party's identification with a top-down, state-centric mode of modernization process during the single-party era, its strong emphasis on secularism, national identity and sovereignty, and its historically proven incompetence to build broad cross-class coalitions.

Though bringing nuanced explanations to this matter, all these views highlight the CHP's deep historical roots in and linkages with the state-centric Turkish modernization, and Kemalism, as its leading ideological guide. In particular, the special link between Kemalism and social democracy has always been subject to various debates. For some arguments, standing as the main obstacle on the way of CHP's further shift to social democracy, Kemalism has appeared one of the main causes hindering CHP's evolution into a Europeanstyle social democratic party. Needless to say, the historical baggage of the CHP, along with its reliance on Kemalism, has inevitably affected the course of social democracy in Turkey by giving it a different flavour. As another fact, the party has always encountered an oscillation between Kemalism and social democracy in terms of deliberating as the primary identifier of the party. Happening particularly during times of crisis, such as electoral defeats or inter-factional clashes, the party was fragmented between rival camps over this issue, and more than once even had key figures split from the party ${ }^{8}$.

However, these views seem to have two main shortcomings. Firstly, in the conceptualization of social democracy, the primary reference continues to be

8 Due to the success of the left-of-center movement led by Bülent Ecevit, the Secretary General, in acquiring the majority of the Party Assembly in the Fourth Extraordinary Congress of the CHP, held in 1967, 47 deputies and senators, headed by Turhan Feyzioğlu, split from the party, and founded the Reliance Party (Güven Partisi). In a similar manner, right after the election of Bülent Ecevit to the post of General Presidency in 1972, 58 deputies and senators departed from the party under the leadership of Kemal Satır, and established the Republican Party (Cumhuriyetçi Parti). In 1973, these two parties merged under the name of the Republican Reliance Party (Cumhuriyetçi Güven Partisi). For more detail, please see Bila (2008). 
made to the European, particularly Western European, model, as the context from which social democracy originated. Preoccupied with the Eurocentric point of view, these views mostly neglect the possibility of adopting and implementing different social democratic models shaped in accordance with domestic specificities, as is the case for many instances such as Latin American social democracy. Considering that even European social democratic model is not possible to be conceived in a uniform sense, the abovementioned approach rather tends to take the authentic conditions present in Western Europe during the construction of the post-war consensus and welfare state model for granted regarding the actual presence and practice of social democracy even in nonEuropean instances. Secondly, the relationship between Kemalism and the CHP, and the SHP, has never been rigid or constant, but prone to conjunctural or pragmatic changes over time, as Kömürcü (2009: 3) asserts. This suggests that despite the overall commitment to the Kemalist principles, materialized in 'Six Arrows', has maintained, the way of evaluating them in light of the changing social, political, and economic conditions has possibly varied for these parties.

Regarding the ideological dimension, the point should also be made on the support base of the pre-1980 CHP. Up until the 1970s, the Turkish economy was mostly characterized by agrarian production, having the overwhelming majority of the population live in the countryside rather than urban centres. This did not produce clear-cut, deliberate segregation between classes, unlike the European setting, in Turkey, generally conceived as a 'latecomer' on the accounts of urbanization, industrialization and flourishing of capitalism (Cem, 1998: 275). Looking from the perspective of a social democratic party, this came to mean the presence of a rather weak organization of the working-class interests, with a burgeoning middle class in general. Due to this aspect relating to the societal framework, the voting base of the CHP was not only made up of the working and lower-middle classes but also consisted of other socioeconomic groups from the late-1960s ${ }^{9}$. As a consequence, the necessity of appealing to other target groups ${ }^{10}$

9 Underlining this point of divergence creating a contrast with European social democracy, Cing1 (2011: 1) similarly asserts that the CHP neither grew out of a workers' movement nor was it founded as a political force rebelling against an unequal system with the primary motivation of transforming it into a more equal one. Rather, the party established a new republican order on the ruins of a collapsing empire and developed reflexes aimed at preserving it, explaining the identification of the party with the state in the eyes of the average Turkish voter for decades.

10 Looking from another side, this necessity can be considered to make sense due to the overly decisive impact of the culturally-driven cleavages, such as religion-secularism, Turkish nationalism-Kurdish nationalism and Alevi sect-Sunni sect on the shaping of left-right axis, rather than socio-economic class fragmentations, in Turkish politics (Kiriş, 2012: 410) 
shaped the ideological and practical priorities of the party in the pre-1980 period as well.

Secondly, it needs to be stated that the CHP's shift to social democracy came into the fore also out of electoral concerns. In contrast to its emergence as a working-class movement in the European context in the late- $19^{\text {th }}$ century, social democracy in Turkey originated as a factional movement within the CHP during the mid-1960s. More importantly, it did not directly show up under the brand of social democracy but has achieved its current shape as a result of an evolution that launched during the same period.

Just like the European countries, a profound socioeconomic transformation was underway in Turkey during the 1960s. Along with rapid urbanization and industrialization, the emigration from the rural to the urban hastened. As the weight of the industrial sector in the economy increased relatedly, the working class showed up as one of the key societal actors. Also, together with the improvement of educational opportunities, the number of people getting educated in universities rose rapidly ${ }^{11}$. This automatically prompted the advent of the students' movement as another influential radical force in the 1960s' Turkey. As these deep socioeconomic changes had repercussions on the political scene, the progressive demands began to be raised by these stated groups more vociferously. Being emblematic of these developments, the Workers Party of Turkey (TIP) entered the Parliament as the first socialist party to be represented ever in the recent political history of modern Turkey, with 14 MPs out of nearly 3 per cent of the votes in 1965 elections.

In such conditions, it was not possible for the established political parties, particularly the CHP, to be indifferent to these incidents. Looking forward to responding to and keeping up with the rising tide of radicalism, and not losing votes to its left claimed by the TIP, the CHP was compelled to achieve clarity in terms of its political and ideological position in the political spectrum. Stemming from its well-known identity as the party leading the modernization period in the aftermath of the founding of the Republic, the CHP underwent an ideological renewal process, beginning with the announcement of the party's position as 'left-of-centre' by the party leader İsmet İnönü in an interview in 1965'12. Owing

11 As the formal data reveal, the number of students getting educated in universities nearly tripled from 25.000 in 1950 to 65.000 in 1960 . For more information, please look at (Karakök, 2011: 95).

12 In its inception, the left-of-center movement, as put forward by the party leader İnönü, did not come to mean an overall change in the party's ideology and program. Rather, this new label corresponded to an attempt content with re-defining party's founding principles, from the prism of the popular concepts of the 1960s, in the form of 
to Bülent Ecevit's commitment and decisive manner, this process ended up acknowledging to be a democratic left party ${ }^{13}$ both programmatically and ideologically, by the party. That is, in the adoption of the social democratic ideology by the CHP, the willingness of the party to rely on new social forces as its electoral repository, along with competing with the TiP for the votes of the progressive, played a crucial role. Relying on this path, it is possible to think that, along with all other reasons, the emergence and progress of social democracy in Turkey also materialized as a result of the external pressures that the CHP felt during the turbulence of the 1960s.

Finally, in relation to the distinguishing organizational aspects of social democracy in Turkey, the CHP was not spared from the problems peculiar to domestic politics. Like all other parties, it was commonplace to come across with patron-client relations in the CHP, as the locus of Turkish social democracy. In a top-down party organization, the relations between party headquarters and the provincial units mostly depended on hierarchical links. Even if the rise of social democracy within the party during the 1970s reinforced the schemes urging the participation of provincial units particularly to the decision-making mechanisms (Ayata, 1995: 84), this structure mostly remained unchanged.

Moreover, the pre-1980 CHP mostly functioned on a factional basis, preventing the exchange of ideas in a straightforward and smooth manner. The conflicts happening, or alliances established among many factions within the party became highly decisive in setting the course of the party, particularly towards the end of the 1970s.

As another diverging aspect of Turkish social democracy on organizational accounts, the CHP was able to establish liaison -albeit limitedwith non-party organizations such as trade unions and left-leaning nongovernmental organizations, as natural allies of a social democratic party. During this period, the party succeeded to establish links with one of the major trade unions, the Confederation of Progressive Trade Unions of Turkey (DISK),

republicanism, democracy, planned economy, étatist development, social justice and reformism (Güneş-Ayata, 1995: 82).

13 Throughout the 1970s, in nearly all party documents and related activities, such as the 'Democratic Left Opinion Forums', the phrase, 'democratic left' was used, instead of 'social democracy', in order to define the ideological leaning of the CHP. Although the content of democratic left did not radically differ from what social democracy offered politically, socially, and economically, this was widely interpreted as a purposeful choice of the then party leader Ecevit to underline the authentic nature of Turkish social democracy and its distancing from the Western European current of social democracy as a pro-Marxist movement in essence. The fact that Ecevit established his new party, with his wife, under the name of the 'Democratic Left Party' after leaving the CHP can be seen as a supportive point for the latter argument. 
known to be the representative of the militant working-class struggle. Through this collaboration, the DISK even declared its support for the CHP in the 1973 and 1977 general elections despite causing many controversies within the Union. However, the coordination established between the CHP and the DISK never achieved the high degree of formal link, for example, between the Labour Party and the TUC (Trades Union Congress) in the UK. As the 1982 Constitution, the primary tangible output of the 1980 coup d'état on legal terms, entirely prohibited the engagement with political issues of non-governmental organizations and trade unions, this much more deteriorated the societal links of Turkish social democracy, and its biggest party SHP, at that time.

\section{Changing Political Environment in the 1980s' Europe and Turkey}

The external dimension of the SHP's ultimate failure is made up of two interrelated factors: the radically changing political environment both in the European and Turkish contexts during the 1980s.

The deep crisis that hit the European social democratic parties came into the surface in the early-1970s, as a mix of many factors. On socio-economic accounts, the post-war consensus settled on the main tenets of social democracy including full employment, high wages and state-led welfare provisions gradually came to an end following a series of events. The global outbreak of the first oil crisis in 1973-197414, the demise of the Bretton Woods system ${ }^{15}$, and the adoption of flexible exchange rates system caused this social democratic model that functioned pretty well for decades in many countries to enter into a precarious period full of uncertainties ${ }^{16}$. In direct contrast to the past 30 years,

14 The first oil crisis, to be followed by the second one in 1979, emerged towards the end of 1973 as the members of the OPEC (Organization of the Arab Petroleum Exporting Countries) decided to put an embargo on the countries considered to back Israel during the 1973 Yom Kippur War. As the targeted nations were mostly in the Western hemisphere, this led to an unexpectedly huge increase in oil prices globally, triggering an economic crisis.

15 The Bretton Woods System was created through the ratification of the Bretton Woods Agreement by 44 participant countries at the United Nations Monetary and Financial Conference held in Bretton Woods, New Hampshire, in 1944. Constituting the main framework of the international monetary and financial order to be settled after the Second World War, the Bretton Woods system generated a regulatory framework based on a set of rules and procedures.

16 In addition to these globally effective challenges, specific political and socioeconomic problems typical of the national contexts of the enquired European 
generally called the 'golden age of capitalism', increasing inflation, mounting unemployment and declining growth rates initiated to characterize many European countries. In turn, as the welfare state schemes fell short of meeting people's demands due to these problems, many socio-economic problems spontaneously appeared in an unprecedented way. Then, this was translated as a downward political and electoral performance for many European social democratic parties such as the Labour Party in the UK, and the Social Democratic Party of Germany (SPD) in West Germany, finding themselves in the opposition ranks from the late-1970s ${ }^{17}$. It was a conspicuous fact that many social democratic parties in Europe began to encounter serious difficulties in keeping a grip on political power.

Marking the crisis of hitherto dominant social democratic ideology, this sober landscape automatically triggered a widespread pursuit for a new model to be settled as the 1980s were approaching. At that point, New Right became overly accomplished in promoting itself as the only credible alternative, as suggested by the well-known motto, 'There is no alternative ${ }^{18}$ '. Symbolizing the uneasy marriage of conservatism and neoliberalism, New Right defended economically neoliberal, politically authoritarian and culturally conservative premises. Primarily accusing the interventionist, state-centred social democratic policies as to the recent socio-economic and political turmoil, New Right promised a radical break with these allegedly ineffective policies. Proving its political and economic prominence over time, New Right also succeeded in capturing political powerand came to be mainly represented by Ronald Reagan in the US and Margaret Thatcher in the UK.

In response to New Right's ascendance, on the other side, European social democratic parties seemed to be mostly incompetent. Facing the collapse of the welfare state model, which had even been accepted by the conservative, rightwing parties in the confines of the post-war consensus, on multiple regards, many social democratic parties in Europe were mostly overwhelmed with their downturn. As a reflection of this mounting crisis, the vanguards of the social democratic ideology in Europe, such as the Labour Party in the UK and the SPD in West Germany were electorally defeated by their right-wing rivals and had to shift to the opposition. This was just the beginning of a long period of recession

countries, having pursued differing paths in their conception and adoption of social democracy, also need to be given credit.

17 The Labour Party lost the 1979 general elections to the Conservatives, led by Margaret Thatcher, and the SPD lost power in 1982 following the vote of no confidence issued over the Helmut Schmidt government.

18 This was the primary motto used by Margaret Thatcher in the 1980s' Britain in order to briefly explain that there stood no other serious alternative to shape the future of the country than Thatcherist New Right. 
that these two parties were going to encounter in the opposition ranks due to successive electoral defeats happening until the late-1990s.

For the South European case, the story proceeded a bit differently but ended similarly to a great extent. Following the ensuing collapse of the dictatorships in Portugal, Greece, and Spain from mid-1970s, the socialist/social democratic parties appeared to be the main bearers of the ongoing democratic transition processes in these countries. This opened the way of political power for the Socialist Party (PS) in Portugal in 1976, the Panhellenic Socialist Movement (PASOK) in Greece in 1981, and the Spanish Socialist Workers' Party (PSOE) in Spain in 1982 (Sassoon, 2010: 596). Unlike its North European equivalent, South European social democracy was having its heydays during the 1980 s - albeit mostly due to the factors exclusive to these national contexts respectively. Nevertheless, as later manifested by their experience in government, South European social democratic parties were similarly challenged by New Right hegemony that established itself during the 1980s, so would ultimately share the destiny of their North European counterparts. For instance, though implementing radical social democratic policies in line with the targets of full employment and high wages during its two years in government between 1981-1982, the Socialist Party (PS) in France made a sharp U-turn, known as la ruptura, under Francois Mitterrand's leadership and embarked on applying neoliberal austerity measures (Sassoon, 2010: 561). In brief, what came to be generally agreed was that once victorious social democratic parties conspicuously underwent into a spiral of long-term crisis that was to last until the 1990s.

For multiple reasons, Turkish social democracy was highly liable to get influenced by the setback of social democracy in Europe. Despite pursuing an authentic line of progress, just like all other non-European cases, Turkish social democracy always tended towards keeping an eye on what was happening in the circles of European social democracy. As a reflection of this fact, the conception and practise of social democracy by the CHP, as the major centre-left party in Turkey, have usually been compared and contrasted with those of the Scandinavian and Western European social democratic parties by politicians, academicians, and even ordinary citizens. Likewise, during the 1980s, for both functioning in a national context similarly dominated by a New Right discourse and setting for itself the ultimate target of evolving into a European-style, 'genuine' social democratic party, the SHP, hence, was not immune to the implications arising from the retreat of social democracy in Europe. Hence, due to the specified reasons, it is not wrong to argue that this turbulent conjuncture for European social democracy also accounted for the historical background of the crisis that Turkish social democracy simultaneously encountered. Moving from this path, then, the radically changing political sphere in the 1980s' Turkey 
can be considered as the second part of the external factors adding up to the SHP's failure.

Even in the immediate aftermath of the 1980 coup, the social democratic ideology seemed to preserve its electoral strength in the political domain, as exemplified by the 30 per cent of the vote garnered by the HP in the 1983 elections. This means that in such a hard time when rules of the democratic game were rearranged following the military takeover, the social democratic politics were still likely to resonate with the masses. More importantly, although the centre-left votes were divided among two major parties, the SHP and the Democratic Left Party (DSP) of Bülent Ecevit, who renounced the entire CHP legacy after 1981, for the entire 1980s, these two centre-left parties pursued an increasingly rising trend in terms of their electoral performances.

Reminiscent of many European social democratic parties, the SHP was primarily challenged by the New Rightist policies of the incumbent ANAP governments. Epitomized under the banner of 'Özalism', the Turkish variant of New Right was represented, and materialized in the form of policies, by the ANAP governments. Inspired by the implementations of Thatcherism and Reaganism, the ANAP governments promised a total break with the pre-1980 Turkey, that had already been denounced by the military junta for producing a deeply polarized and antagonistic political system. Adhered to a ground-breaking mentality change in general, Turkish New Right focused its attention mainly on economic, social and political grounds, compelling the SHP to keep up with this dazzling transformation.

On economic terms, the ANAP put all the blame on the interventionist, and protectionist policies, as applied before 1980, prioritizing the share of the state sector in the economy. With the intention of creating an efficiently and effectively functioning, 'open' economy, the Özal governments embarked on radically opening up the Turkish economy to the global effect. In order to undertake the neoliberal transformation of the Turkish economy for assuring its integration with global markets, the ANAP governments liberalized the economy via different measures. Among these measures, in order to decrease the wages, these governments took all the required steps to break the power of trade unions and the organized working class in Turkey. In spite of proposing the idea of contracting the state, the end of the ANAP period saw the expansion of the public sector, yet in the advantage of narrow interests.

In terms of social transformation, the Turkish New Right made the primary emphasis on sectarian/communitarian interests out of its conservative agenda. All the collectivist demands raised by different segments of society were labelled as outdated and obsolete. Allocating much more space to religion in social life, 
the ANAP assumed the mission of conveying cultural conservatism within the societal realm.

Finally, on political accounts, the ANAP embarked on sustaining the apolitical, non-ideological approach to politics, as aggressively upheld by the military regime before. Conceiving politics mostly as a technical matter isolated from the 'antagonistic and destructive' effect of ideologies, the ANAP governments attributed special importance to the expertise of technocrats. In tune with this non-ideological manner, the party showed up in the political scene with the ambitious claim of amalgamating four primary ideological strands, including economic liberalism, political conservatism, nationalism, social democracy ${ }^{19}$, but the first two proved to be the most influential ones in time.

Against this upheaval brought into the fore in the hands of the ANAP governments, the SHP initially succeeded in developing a reliable agenda with the commitment to totally reversing it in the interest of the labourers and the disadvantaged, as will be explained in the next part. Yet, from the late-1990s, due to a number of factors, the SHP remained content to criticize the neoliberal policies of ANAP governments, without coming up with credible policies as an alternative. Instead, the party seemed to be inclined to acknowledge the neoliberal framework established by the ANAP governments as one of the inescapable realities of the upcoming period (Kömürcü, 2010: 158), so happened to adopt it with less hesitation.

In the second round, beginning from the late-1980s, noteworthy changes took place in the Turkish political framework. Under the effect of the "extremist turn' in the political setting, the political party system underwent another crucial transformation process, the effects of which are still possible to be observed. In this respect, the voters initiated to vacate the political centre of the left-right continuum, and much more moved towards the far right, along with slightly to the left (Kalaycıoğlu, 2002: 54). This means that following the increasing shift of the Turkish electorate from the centre-left to the centre-right as of early-1980s, a greater change happened in the general voting behaviour as a result of a further shift from the centre-right to the radical right since the mid-1980s (Bila, 2008:

19 According to Ergüder (1991: 156), sensing the centrist and pragmatic leaning of the Turkish electorate after the conflict-driven politics of the 1970s and three-yearinterregnum under the military junta, Özal's ANAP primarily attempted to attract these newly occurring tendencies of the electorate via emphasizing themes such as 'softening', 'tolerance', 'conciliation', and 'policy-oriented dialogue'. Kalaycioğlu (2002: 52) argues that the 'four strands' view was nothing but an identity-defining myth for the ANAP. 
345). ${ }^{20}$ In a complementary sense, the electoral behaviour changed in a direction boosting the political fortunes of the far-right parties, such as the Nationalist Work Party (MÇP) and the Welfare Party (RP) ${ }^{21}$. Parallel to the steadily declining influence of the centre parties both in the left and in the right axes, those extremist parties proposing nationalist and radical Islamist views were in rising command of the political agenda. Then, these conjunctural changes radically shaped the political sphere in which culturally-driven ethnic and religious issues mattered more than ever.

Under the effect of this drastic transformation predicating the political system on a cultural and peripheral, rather than on a functional and centreoriented, ground, the SHP, like its centrist rivals, was seriously challenged by those far-right parties. Noticing that responding to such new trends turned out to be its fundamental challenge, the SHP leaned towards several initiatives ${ }^{22}$ reflecting the party's updated approach towards such 'hot' topics. ${ }^{23}$

Strained by these radical changes in the European and domestic contexts, the SHP deeply suffered from them, hastening its retreat particularly from the late-1980s. The party made frequent attempts to keep up with these recent challenges. However, along with causing mixed responses, those steps mostly remained insufficient in putting an end to the serious party infighting on its future political route, and, more importantly, in solving the ensuing legitimacy crisis of the party concerning its actual political position.

20 In this section, Bila gives place to the results of a research carried out by TÜSES on changing trends in the electoral preferences of the Turkish constituency during the late-1980s and early-1990s.

21 These parties mostly capitalized on the 'cultural clash' argument, which they have argued to predate to the foundation of the Republic, between pro-Republican modernizing elites and the 'genuine' public they have claimed to represent.

22 For instance, the SHP took bold steps in terms of promoting the cultural rights of Alevis and Kurds at a time when no other party dared to do so, at the expense of questioning the anti-democratic nature of civil-military relations in Turkey (Ayata and Güneş-Ayata, 2007: 217).

23 As stated by Ayata and Güneş-Ayata (2007: 217), the SHP embarked on the first serious attempt to find a non-military solution to the Kurdish problem in the form of a deal to integrate radical and militant Kurdish nationalism into the mainstream multiparty politics, as symbolised by the electoral alliance of the party with proKurdish People's Labour Party (HEP) ahead of the 1991 parliamentary elections. Moreover, on the Kurdish Question, the SHP published a party report which stirred many controversies at that time. For more information, please see SHP (1990). 


\section{Intra-Party Turmoil in the SHP}

In this part, the intra-party turmoil ${ }^{24}$ that unequivocally caused a downturn for the SHP will be elaborated. Likely to be envisaged as parts of a circle, three constitutive factors, namely the organisational crisis, ideological fluctuations, and declining electoral fortunes of the party had a complex impact of feeding each other, so constituted the integral elements of the larger crisis the party experimented.

\section{i. Organisational Crisis}

From its inception, the SHP had a crisis-ridden nature on organizational accounts. Directly influencing the institutional strength and the relations between the party headquarters and the local branches, the organizational crisis, taking place on different degrees, accounted for a huge portion of the unrest inside the party. Linked with factors concerning the reconstruction of domestic politics in the post-coup era, the centre-left politics and the party itself, this crisis turned out to have multiple dimensions.

On the one hand, the SHP was fiercely challenged by the legal restrictions brought by the military administration on the organisational aspects of the post1983 political parties. As one of the inevitable parts of the military regime's grand project of transforming the deeply fragmented and polarised political system of the pre-1980 period, the legal restraints and organisational impediments were put forward right after the decision of returning to the multiparty democratic regime once again. This came to mean that after three-year interlude period under the military rule, the MGK was committed to the primary goal of establishing a 'controlled' democratic system under the military tutelage through different official and non-official means.

Although many visible and invisible organisational restrictions were designated for all the political parties, as the November 1983 elections approaching, the centre-left parties became the most negatively affected ones. This stemmed from both the structural features of these parties and the notorious prejudices, and 'allergies', of the generals against the left. In that vein, for instance, the requirement of having minimum 30 constituent members, to be approved by the MGK, for a party to contest the 1983 elections was designated

24 The phrase of 'intra-party turmoil' does not necessarily refer to inter-factional clashes, believed to emerge as a reflection rather than the cause of the internal crisis, but mainly identifies a much broader structural/conjunctural crisis that the party experimented, arising from the cyclical interaction among three factors that will be elaborated. 
to either diminish or totally paralyze the organisational capability of the newly founded centre-left parties. The HP, generally considered as a 'collision (muvazaa) party', was able to participate in the elections through passing this 'threshold' of constituent members despite facing many vetoes. On the other hand, İnönü's SODEP was denied from competing in the elections due to the successive vetoes practised by the military regime on its constituent members. ${ }^{25}$ In the short run, this fact had a negative effect on the organisational strength and durability of the SODEP, the predecessor of the SHP, as a party that was already dealing with many issues in the founding phase.

More importantly, then, the antidemocratic provisions of the new Constitution, the Law on Political Parties and the Election Law ratified during the lifetime of the military rule dealt a more serious blow to the organisational capacity of the SHP. In addition to the restrictive provisions of the 1982 Constitution, national and local electoral thresholds were created by the Election Law. As if these were not enough, many legal prohibitions were erected by the Political Parties Law on both forming women and youth branches and establishing formal linkages with labour unions. Then, all these legal limitations proved to be highly decisive in the organisational progress of the SHP. In particular, the latter bans had a detrimental impact on the organisational development of the SHP as a social democratic party in desperate need of the organisational activities of its members and supporters in order to promote its cause on the parliamentary and societal grounds. As can be understood, in the post-1980 political climate, the primary centre-left party of Turkish politics was legally exempted from two highly essential sources, providing an undeniable impetus to the rising popularity and organisational dynamism of the CHP throughout the 1970s.

On the other hand, the clientele mechanisms, offering multiple political favours in the central bureaucracy and municipalities for the local members of all political parties before 1980, were strictly outlawed after the 1980 coup (Güneş-Ayata, 2002: 116). Due to this fact, the local party officials in the SHP, as it was the case in other parties, increasingly tended towards entrepreneurship (Güneş-Ayata, 2002: 116). This radical transformation in the patron-client linkages between the party headquarters and the local organisations posed a transformation, particularly in the local political mechanisms. Although it was not recognised at the very beginning, this conjunctural shift induced a profound change in the organisational priorities of the local branches of the party. Even if

25 In order to overcome this hurdle, the SODEP kept submitting new lists of constituent members; but was intentionally rejected by the MGK in each turn. In this process, even Erdal İnönü, the son of İsmet İnönü as the 2nd President and one of the leading founders of the Republic, was disapproved by generals. 
an overall generalisation does not make sense, many local branches of the SHP initiated to emphasize the material benefits in their organisational activities, for the disadvantage of the political and ideological premises of the party. As time passed, this situation triggered the occurrence of unofficial and uncontrolled relations, which irreversibly caused many problems particularly in the aftermath of the 1989 local elections victory, within the peripheral circles of the party.

As the final factor negatively affecting organisational maintenance of the SHP, the fragmented structure of the centre-left represented by three respective parties by the early-1990s ought to be mentioned. Although the SHP seemed to prevail over Ecevit's DSP on electoral accounts during the decade of the 1980s, none of these parties achieved organisational stability in a sphere where both parties accused each other of 'dividing the left'. As the intra-party squabbles within the SHP intensified towards the late-1980s, the departures of the SHP members from the central and local cadres of the party were routinised. This ongoing flux among the members of these two parties appealing to the same electoral ground reasonably created a real threat on the organisational maintenance and coherence of the SHP. When the CHP was re-established in 1992, the already present fragmentation in the parliamentarian left deepened more. Although this situation forced a merger between the SHP and the CHP in 1995, this unification proved insufficient to solve the existent organisational problems of the 'united' CHP.

\section{ii. Ideological Fluctuations}

Ideology always remained among the top priorities of the SHP. In the harsh political climate of the post-1980 coup, the political and ideological vacuum borne out of the CHP's absence was intended to be filled by the ongoing discussions on the present and future of social democracy. Contributing to setting the ideological trajectory of the party, these discussions provided the emergence of a vibrant sphere in which a broad range of ideas concerning the social democratic ideology was easily exchanged. However, as these fruitful exchanges turned into detrimental controversies mostly settled on the ego-centric battles among key party figures, the party underwent a period of ideological turbulence, which added up to the broader structural-conjunctural crisis of the SHP along with other two factors.

Promoting itself as the real inheritor of the CHP outlawed in 1981, the SHP devoted all its energy to carrying the social democratic evolution within the CHP line to a further stage via refraining from repeating the mistakes of the pre-1980 period. Acknowledging the re-orientation of the political system on a functional, rather than a cultural, basis that happened from the 1970s (Tachau, 1991: 114) as its major reference point, the SHP committed itself to pursuing a social 
democratic agenda, so focused on developing its economic, social and political premises accordingly. Underlining the primary importance of the state, coupled with economic planning and state economic enterprises (Mango, 1991: 176) ${ }^{26}$, the SHP primarily aimed at representing the wage-earners and economically disadvantaged and unprivileged masses within the society, as the pre-1980 CHP did. Under the 'Planning' section of its first Party Programme, the importance attributed to planning by the party was explained as given below:

"The SHP aims at the optimal usage of resources; resolution of the economic and social problems, such as unemployment, by accelerating economic development; the realisation of industrialisation; achieving independence in external economic relations and a fairer distribution of income, and believes that these objectives can only be achieved through an effective economic planning. The SHP counts planning as highly necessary in order to prevent the economy from sliding into depressions" (SHP, 1985: 18).

Likewise, in the same document, the party explicitly stated under the section of 'Working Life' that;

"The SHP is against the exploitation of labour. Based on this view, it considers as its mission the reorganisation of the working life in a way that would prevent this exploitation. In this regard, the SHP re-explains that it stands on the side of the economically weak" (SHP, 1985: 45).

In addition to its socio-economic perspective, the SHP also raised the flag of wide-ranging democratisation in the post-coup political environment via arguing for the extension of civil, social, and political rights; emphasising the rule of law; and pushing for the amendment of the state-centric 1982 Constitution with the ultimate objective of empowering the individual against the state (Ayata and Güneş-Ayata, 2007: 217).

26 As stated by Güneş-Ayata (1993: 42), the SHP also economically underlined the significance of rapid industrialization, a system of progressive taxation, and a more egalitarian distribution of wealth. 
Ankara Üniversitesi SBF Dergisi • 75 (1)

Table 1. Periodisation of the SHP Era

\begin{tabular}{|c|l|}
\hline $\mathbf{1 9 8 3 - 1 9 8 7}$ & Formation of the party and party organisation \\
\hline $1983-1985$ & $\begin{array}{l}\text { Establishment of the SODEP and its merger with the HP (emergence } \\
\text { of the SHP) }\end{array}$ \\
\hline $1985-1987$ & $\begin{array}{l}\text { Institutional organisation of the SHP and achieving programmatic } \\
\text { clarity }\end{array}$ \\
\hline $\mathbf{1 9 8 7 - 1 9 9 1}$ & Internal and external power struggle \\
\hline $1987-1989$ & $\begin{array}{l}\text { Democratisation struggle; intense debates on the party identity and } \\
\text { ideology; inter-group power clashes }\end{array}$ \\
\hline $1989-1991$ & $\begin{array}{l}\text { Shift to the centre; the quest for returning to the CHP roots; İnönü- } \\
\text { Baykal conflict }\end{array}$ \\
\hline $\mathbf{1 9 9 1 - 1 9 9 5}$ & DYP-SHP coalition government \\
\hline $1991-1993$ & $\begin{array}{l}\text { Striving for realising democratisation and putting social democratic } \\
\text { policies into effect as a coalition partner }\end{array}$ \\
\hline $1993-1995$ & Surrender to neoliberal hegemony and return to Kemalism \\
\hline
\end{tabular}

Source: Kömürcü, Derya (2010), Türkiye'de Sosyal Demokrasi Arayışı (SODEP ve SHP Deneyimleri) (İstanbul: Agora): 263.

As figured out in Table 1, particularly following the first phase of completing the institutional organisation of the party, the SHP gave much more primacy to democratisation as the primary topic in its political agenda, followed both in its external power struggle and throughout the coalition partnership with the DYP.

Due to setting its political and socio-economic premises based on its indisputable alignment with the social democratic ideology, the SHP performed well in terms of reaching ideological clarity in its earlier phases, so broadened its support base among the pre-1980 CHP constituency. Bolstered by constructive intra-party discussions, not so much possible to coincide in other mass parties positioned in the left-right continuum at that time (Bora, 2007), this process opened a new phase for Turkish social democracy that reached its climax in the local election victory of the SHP in 1989.

From its very first days, the SHP turned out to be a political party characterised by a highly complex membership profile on ideological accounts both in its lower and higher ranks. Revealing its 'pluralist' internal composition, 
the SHP hosted many ideologically and politically different personalities -and tendencies- ranging from new rightists, pragmatist Kurds, apolitical Alevis and new-generation bureaucrats to radical leftists, leftist Kurds, social democratic Alevis and Republican bureaucrats (Kozanoğlu, 1992: 37). In terms of capturing top positions within the party, all these active groups, wings and political figures embarked on a strict competition, also entailing the attempts of each to set a new ideological route for the SHP.

Related with this point, it was not a hidden fact that the SHP always consisted of three major factions, namely pro-İnonü faction, Baykal's faction ${ }^{27}$ and the 'Left Wing'. However, in the face of the anti-democratic restructuration of the political arena and mounting socio-economic inequalities directly targeting the working class and the disadvantaged, potential clashes among these factions were postponed for a while so as to produce an effective and unitary response. Despite standing as a potentially problematic aspect, this 'multi-factional', internal composition of the party, frequently resembled a 'coalition of factions', functioned as one of the primary elements contributing to the rising political and societal dynamism of the SHP until the 1991 general elections (Bora, 2007). That's why, in spite of proposing ideologically differing views, this schism accounted for a significant balance via serving the ideological cohesion of the party in the aftermath of the 1980 coup d'état.

After the pre-1980 CHP politicians, particularly Deniz Baykal, joined the SHP ranks following the removal of their political bans at the end of the 1987 referenda, yet, this sensitive ideological balance kept among various factions tended to be spoilt. Beginning from this crucial milestone, the constructive ideological negotiations were suddenly displaced by destructive factional clashes that caused the SHP to be publicly perceived as a deeply fragmented party, like the pre-1980 CHP in its last years. Due to the endless attempts of Baykal, the Secretary General of the party at that time, for replacing İnönü as the new leader, the party had to convene three successive extraordinary congresses, all of which resulted in Baykal's defeats against İnönü, just within two years. ${ }^{28}$

As an important part of this leadership struggle, the SHP leaned towards revising its ideological premises and strategies in compliance with the notion of 'pragmatism', one of the 'magical' words of the 'new times' discourse widely propagated by the New Right throughout the 1980s, despite having a specific

27 Although Deniz Baykal was banned from active political life by generals for ten years since 1982, he continued to be de facto involved in all the activities within the SHP thanks to his faction comprising old-CHP politicians allying with him.

28 Due to this process, the SHP was increasingly identified as 'the party of extraordinary congresses' not only by rival politicians such as Ecevit but also by many columnists in the media at that time. 
concern with ethical preferences of the left, namely social justice and social welfare (Erdoğan, 1992: 32). Pledging to transfer the ideological evolution taking place in the West European social democratic parties since the 1980s to the SHP (Kömürcü, 2010: 425), the 'New Left' approach emerged as the primary representative of this pragmatist turn within the SHP. Baykal, enshrined as the spokesperson of the New Left, argued that one of the chief remedies for the recent ideological crisis of the SHP was to strive for more welfare and faster economic development via going beyond the struggle for political democracy and fair distribution, which actually had its roots, he claimed, in the 'Third World leftism' (Baykal, 1991: 3-4). According to him, since étatism was not a sacred concept for social democrats, the economic model that would be proposed by social democrats ought to be market economy in Turkey (Baykal and Cem, 1992: 29).

Highly influenced by the popular debates on the future of social democracy in the national and European settings, the SHP got already engaged with two concurrent debates on whether the left-right distinction was still present and whether the party lost its leftist identity (Kozanoğlu, 1992: 37-38). However, as the pragmatist tendency prevailed within the party as a result of these debates, the SHP was commented to be increasingly adapting both to the neoliberal economic orthodoxies of these times and to the related hegemonic conception of the political-social domain put forward by Özalism (Bora and Erdoğan, 1999: 29). In compliance with Baykal's -and his faction's- pragmatist goal of coming to power by attracting 'all voters' just like mass parties of the centre-right such as the DYP and the ANAP, the SHP turned into a new ideological road. Moving from this path, in the 1991 Election Declaration, the SHP was re-defined as a 'grand political party addressing the entire society' (SHP, 1991a: 27). In a similar fashion, in the 'Economic Restoration and Progress Programme', the party promised to compensate for the income losses encountered not only by workers, peasants, civil servants and craftsmen but also by the productive portions of the capital (SHP, 1991b: 26).

Proceeding in this new route, then, the party relied on two major pillars. First of all, the prominent party officials gradually gave up on problematising both the free market economy and neoliberal economic policies of the ANAP governments. In this process, the party initially developed concepts such as 'social market economy' -akin to the West German SPD promoting Soziale Marktwirtschaft-and 'democratic market economy' with the concern of keeping the ideological alignment with the core social democratic agenda intact (Bora and Erdoğan, 1999: 29). According to this conception, although the primary goals such as balanced economic growth, fairer redistribution and the expansion of social justice mechanisms still kept their importance, the free market economy seemed to be 'inevitable' for the social and economic progress of the country. In 
the Economic Restoration and Progress Programme, the SHP defined the concept of social market economy with these words:

\begin{abstract}
"There are two major prerequisites for the market to serve the expected benefits. First of all, an exact array and a fair distribution need to exist concerning the distribution of income. Secondly, a robust competition zone ought to be created. In order for the alleviation of such deficits, the state needs to take measures in accord with, not against, the functioning of the market, together with constituting the sufficient sphere for enabling the market to bear the expected advantages. The SHP defines this last phase on the way towards passing into a genuine market economy as 'social market economy"' (SHP, 1991b: 14).
\end{abstract}

In line with this understanding, Baykal argued that since major preconditions for a stable democratic structure in Turkey were industrialisation, economic development and economic growth (SHP, n.d.: 24, 26), Turkish social democrats ought to value production as well as redistribution, to be guaranteed by the defence of a 'market economy having social sensitivities' (SHP, 1989: 78,12 ). In another speech, Baykal explained the 'inevitability' of the free market economy with these words:

"Social democrats need to propose the market economy regardless of any ideological complexes, and everyone needs to recognise that. The market economy is the primary point of departure for the upcoming economic restructuration ahead of us" (Baykal and Cem, 1992: 62).

It is possible to observe the adoption of this approach as the general party policy via the rhetoric shift happening in conceiving the market economy and setting the socio-economic priorities by the SHP, as depicted in Table 2 below on the basis of four major party documents. In the first Programme of the party approved in 1985, the market entity was not totally denounced and a special emphasis was made on its multiple functions related with the production process (SHP, 1985: 18). However, the SHP clearly indicated in the same document that the market itself caused many socio-economic problems, involving nonegalitarian growth, regional differences, economic malfunctions and unjust distribution of income, which could just be solved with the help of economic planning.

The importance attributed to democratic and participatory planning for the economy remained untouched for the 1987 Election Declaration. However, in the very same document, the SHP revealed its tendency of conceptualising the market economy with little emphasis on the socio-economic problems it created and on the necessity of economic planning (SHP, 1987). 
As issued in the same document and the Economic Restoration and Progress Programme, the market economy was incrementally assigned a positive meaning along with the promise of taking the required steps for ensuring the smooth functioning of the market like its Western equivalents (SHP, 1987: 26; SHP, 1991b: 13).

Table 2. Approach to the 'market economy' and socio-economic priorities of the SHP in selected party documents

\begin{tabular}{|c|c|c|c|c|}
\hline & 1985 Party Programme & $\begin{array}{l}1987 \text { Election } \\
\text { Declaration }\end{array}$ & $\begin{array}{l}1991 \text { Election } \\
\text { Declaration }\end{array}$ & $\begin{array}{c}1991 \text { Economic } \\
\text { Restoration and } \\
\text { Progress Programme }\end{array}$ \\
\hline 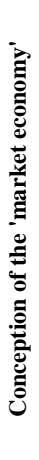 & $\begin{array}{l}\text { *Emphasis on multiple } \\
\text { functions of the market } \\
\text { in arranging different } \\
\text { factors and stages of } \\
\text { production } \\
\text { *Crucial problems } \\
\text { emanating from the } \\
\text { functioning of the market } \\
\text { *Key role of economic } \\
\text { planning in the } \\
\text { prevention of market- } \\
\text { based problems }\end{array}$ & $\begin{array}{l}\text { *Boosting the goods and } \\
\text { services circulating in } \\
\text { the market via providing } \\
\text { the consumption- } \\
\text { investment equilibrium } \\
\text { in economic plans } \\
\text { *Emphasis on } \\
\text { democratic and } \\
\text { participatory planning }\end{array}$ & $\begin{array}{l}\text { *Establishment of the } \\
\text { 'social market economy', } \\
\text { as a displacement for the } \\
\text { 'wild market economy' }\end{array}$ & $\begin{array}{l}\text { *Long-term objective of } \\
\text { turning Turkey into a } \\
\text { country where the } \\
\text { market economy would } \\
\text { function similar to its } \\
\text { Western equivalents } \\
\text { *Establishment of the } \\
\text { 'social market economy' } \\
\text { *Reaching an } \\
\text { equilibrium between } \\
\text { competition and } \\
\text { economic planning in } \\
\text { accordance with the } \\
\text { premises of 'competition } \\
\text { as much as possible' and } \\
\text { 'planning as needed' }\end{array}$ \\
\hline 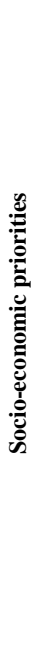 & $\begin{array}{c}\text { *Economic development } \\
\text { based on } \\
\text { industrialisation } \\
\text { *Achieving social justice } \\
\text { by redistribution in } \\
\text { favour of the labourers } \\
\text { *Establishing an } \\
\text { economic structure in } \\
\text { which labourers would } \\
\text { freely put their weights } \\
\text { *Pursuing a multi- } \\
\text { dimensional and } \\
\text { independent policy line } \\
\text { in external economic } \\
\text { relations } \\
\text { *Creating a productive } \\
\text { and resource-bearing } \\
\text { economic structure }\end{array}$ & $\begin{array}{c}\text { *Concurrent } \\
\text { achievement of fair } \\
\text { distribution, rapid } \\
\text { economic development } \\
\text { and higher rates of } \\
\text { production } \\
\text { *Reshaping the } \\
\text { economic structure in } \\
\text { line with the primary } \\
\text { objective of ending all } \\
\text { sorts of exploitation on } \\
\text { labour } \\
\text { *Strengthening the social } \\
\text { state framework that } \\
\text { would enable the } \\
\text { labourers to freely get } \\
\text { organised in defence of } \\
\text { their interests } \\
\text { *Resolution of the } \\
\text { inflation issue as the top } \\
\text { socio-economic problem } \\
\text { *Reserved support given } \\
\text { to privatisation }\end{array}$ & $\begin{array}{c}\text { *Planned and unitary } \\
\text { implementation of the } \\
\text { policies against crisis, } \\
\text { coupled with the policies } \\
\text { striving for } \\
\text { industrialisation and fair } \\
\text { redistribution } \\
\text { *Combined application } \\
\text { of private } \\
\text { entrepreneurship and } \\
\text { state interventionism } \\
\text { *Creation of an } \\
\text { economic structure } \\
\text { functioning based on the } \\
\text { principles of } \\
\text { international efficiency } \\
\text { and competition } \\
\text { *Drawing upon foreign } \\
\text { investment in providing } \\
\text { industrialisation, } \\
\text { economic development } \\
\text { and technological } \\
\text { progress }\end{array}$ & $\begin{array}{l}\text { *Establishment of a } \\
\text { 'flexible' economic } \\
\text { structure functioning } \\
\text { based on the formula of } \\
\text { 'high wages for the } \\
\text { labour - highly efficient } \\
\text { economy' } \\
\text { *Flexible restructuration } \\
\text { of the economic sectors } \\
\text { through the concurrent } \\
\text { and complementary } \\
\text { practise of the import } \\
\text { substitution and export- } \\
\text { based growth models } \\
\text { *Necessity of attracting } \\
\text { foreign direct investment } \\
\text { to the Turkish market in } \\
\text { the suitable economic } \\
\text { and political atmosphere } \\
\text { of the post-Cold War era }\end{array}$ \\
\hline
\end{tabular}

Parallel to the altering conception of the market, the socio-economic priorities of the party also changed in time. It is not possible to say that the SHP 
totally abandoned the social democratic goals of redistributing the wealth and income in a fairer way and expanding the social state network. However, in tune with the long-term objective of coming to power by addressing the whole society, class-based references, such as putting an end to all sorts of exploitation of labour, possible to coincide in the former party documents, were gradually reduced.

As depicted in Table 2 above, the party began elaborating more on achieving rapid economic development and higher rates of production, coupled with combating the inflation problem, as much as its concern with redistribution (SHP, 1987). In fact, following the adoption of the social market economy approach, the SHP attempted to generate an equilibrium between economic competition and social justice with the intention of adjusting to the newly occurring 'realities'. Much more stressing the principles of international efficiency and competition, the SHP also underlined the necessity of jointly practising private entrepreneurship and state interventionism, alongside importsubstitution and export-based growth models (SHP, 1991a: 10-11; SHP, 1991b: 23). Overlapping with this quest for setting a balance, the SHP adhered to the flexible restructuration of the economy in accord with the goal of constituting a highly efficient economy but did not also neglect to promise higher wages for the labourers (SHP, 1991b: 19, 24). By the way, the issues of privatisation and foreign direct investment were approached from a rather 'neutral' standpoint and were mainly discerned in relation with the themes of international competition, efficiency and effectiveness (SHP, 1987: 31; SHP, 1991a: 11; SHP, 1991b: 24, 32).

In line with this novel stance, the party started developing practical 'policy packages' particularly towards socio-economic problems, in a manner reminiscent of Özal's ANAP and Demirel's DYP. Revision of the 'Implementation Policies' covering the economic, social, cultural, accommodation, security, and justice policies of the SHP at the Third Extraordinary Congress in 1987 and declaration of the 'Economic Restoration and Progress Programme', with the motto of 'New Vision', in 1991 came into the fore as a result of this new perspective.

Issuing the ideological ambivalence of the party, Necmi Erdoğan explains this explicit leaning of Turkish social democracy in the context of the SHP as stated below:

"Social democracy does not emerge even as a partial society-world imagination that questions the existing modes of social relations -in one or the other way but- on an essential ground and that aims to transform these modes on the basis of the forms of humanitarian existence, whose presence is considered to be necessary. On the contrary, it seems to appear as a 
project-based understanding predicated on the presupposition of the hegemonic definitions of the social-political domain and forms of humanitarian existence and, moving from this path, that tries to develop 'rational', 'reasonable', 'optimal', 'technical' solutions to the problems. Turkish social democracy seeks to identify itself with an 'expediencybased', 'technicist' package of measures, that is, with 'policy', instead of 'politics' likely to be defined as the embodiment of a system of ethical preferences" (Erdoğan, 1992: 35).

The second part of this new ideological strategy was accounted for by the infamous attempt at 'bringing the state back in' within the party's ideological priorities. On ideological terms, according to Kömürcü (2010: 260-262), the intra-party competition actually took place between two rival groupings, namely the one proposing the modern social democratic ideology and the one suggesting turning back to the traditional Kemalist approach that dominated the CHP before the mid-1960s. At the end of this struggle, he argues, the supremacy of the second faction was confirmed, as revealed in Table 1 for years of 1993-1995. ${ }^{29}$ Needless to say, the majority of the social democratic wing was committed to the Kemalist principles, as well. Yet, it would not be wrong to assume that this inter-factional clash condensed among two axes on the issue of whether the SHP would continue to define itself as a social democratic party based on the socio-economic cleavages or would pursue a seemingly new path settled on the playground of the cultural cleavages from a state-oriented perspective. Encountering many internal and external challenges, such as the conjunctural political shift to the right during the 1980s, the mounting inter-factional strife within the party, the rising importance of the ethnic and religious matters in the domestic politics, and the huge political space opened to the state in dealing with these matters, the SHP perceived re-embracing the state-oriented approach as the primary solution towards all such problems by the early-1990s.

At the time the inter-factional struggle was continuing, the SHP had already been conceived as a party being at unease with its ideological alignment due to its fragmented and weak public standing and the pragmatist ideological turn. Missing the historical opportunity of launching a counter-hegemony project of the left against the persistently declining New Rightist partial hegemony project of Özal's ANAP (Bora and Erdoğan, 1999: 28), the SHP seemed incompetent in the face of its deepening ideological turmoil, alongside losing most of its distinctive ideological differences with the centre-right parties.

29 Likewise, Esen (2005: 95) establishes a direct connection between the political turmoil of the SHP and the ideological crisis of Kemalism that has lost its 'hegemonic' control over the society. 
As the SHP was popularly compelled to decide on the long-awaited unity of the left, it ultimately went into a formal unification with the re-opened CHP, under the banner of the latter, in 1995. Although the social democratic approach to be assumed by the 'new' CHP kept attracting public attention, the once primary position of social democracy in the party agenda, as was the case particularly during the earlier phases of the SHP period, had already been a thing of the past.

Maintaining the ideological 'renovation' launched in the last years of the SHP, the CHP kept undertaking novel ideological openings in its approach to social democracy. To this end, initially, the New Left approach, already summarized in the previous part, strengthened its grip on the ideological repositioning of the post-1992 CHP. Following that, as the end of the 1990s approaching, in an attempt to stop the downward electoral performance of the party, Baykal's CHP once again came up with a new ideological discourse called as the 'Anatolian Left'. Defined as an overall scheme likely to enable the party to catch up with the 21 st century, the Anatolian Left aimed at reaching an authentic form of social democracy out of the synthesis between the distinguishing aspects of Turkish society, culture, and history, on the one side, and universal principles of social democracy, on the other side (Hakan, 2001: 41). However, these ambitious steps taken by the party leadership to reform Turkish social democracy did not resonate sufficiently with the electorate. Then, following its return to the Parliament after the 2002 elections, the CHP ended up embracing a more nationalist-laicist approach that had little to do with social democracy. From then on, without much emphasizing the social democratic ideology in shaping its economic, political, and social premises, the CHP chose an alternative policy path mainly based on identity politics (Emre, 2015: 403404). ${ }^{30}$

\section{iii. Declining Electoral Support}

The SHP saw a steady decline in its electoral fortunes from the high point achieved in the 1989 municipal elections up until its merger with the CHP in 1995.

At that point, the question of what the declining electoral backing has to do with the internal crisis of the party can be asked. In fact, the dropping rates of

30 Emre (2015: 404) indicates that due to the neglection of social democracy by the CHP leadership in the shaping of the party policies, the present parliamentary politics is primarily shaped by two debates between secularism-political Islam and Turkish nationalism-Kurdish nationalism, with the social democracy still expected to launch new discussions on egalitarianism-non-egalitarianism and freedom-authoritarianism. 
the party in the polls mostly functioned as a catalyst triggering the abovementioned two main factors including the organizational crisis and ideological fluctuations. In a cyclical way, as the party did not perform well on electoral terms, the party dissidents much more eagerly pressed for a change in the ideological trajectory of the party, with the anticipation of keeping the existent support base intact alongside guaranteeing the influx of new votes. This debate, mostly taking place in the form of a battle among rival factions instead of a smooth ideological soul-seeking, resulted in the split of many members from the party, mostly in favour of the DSP or the re-born CHP. After a certain point, all these negativities happening in relation to the party translated into a weak public image of the SHP that paved the way for ongoing electoral defeats again.

Turning back to the issue of the electoral downturn, it seems as a must to state that the SHP actually made a promising start into the political life, as proven by the rising popular support it enjoyed from its early days, setting the scene for the 1989 election victory. In this respect, the party proved accomplished in having a stronghold especially over the socio-economic groups previously aligned with the pre-1980 CHP, such as the working class and the urban poor. However, rising electoral fortunes of the party were reversed under the effect of two factors.

As the first factor, the SHP experienced significant difficulties in adapting to the newly shaping political environment in which the political party system and electoral behaviour underwent a deep transformation due to the recent 'extremisation' and 'peripherialisation' of politics. As mentioned in the second part of the article, the party remained mostly incapable of developing effective and up-to-date social democratic policies towards these challenges while dealing with its internal problems, so lost many votes to radical right parties such as the pro-Islamist RP, particularly in the case of Sunni Kurds (Güneş-Ayata, 1993: 44). As the poor public profile of the SHP vis-à-vis pressing issues urged many voters to bolster such extremist parties, these parties established a rising monopoly over certain groups that had previously opted for social democrats, including the SHP.

As another factor underlying the low electoral performance of the party, the SHP was inevitably influenced by the devastative race with other centre-left parties. In fact, at the beginning, the SHP seemed to be not much affected from the de-facto division of the centre-left votes between itself and Ecevit's DSP due to its predominance over the social democratic votes throughout the 1980s. As depicted in Table 3, parallel to the SHP's steadily increasing showing from one election to another, the sum of social democratic votes also enjoyed a rising trend and reached approximately 38 per cent of the total votes in the 1989 municipal elections. 
However, because of the mix of many factors explained, the party initiated to lose power. Particularly, beginning from the early-1990s, in contrast to the DSP's consistently increasing votes in the polls, the SHP suffered ongoing losses in its core electorate (Kiriş, 2012: 406), both on socio-economic and ethnoreligious accounts. For instance, a remarkable portion of the working class previously voting for the SHP increasingly preferred

Table 3. Electoral performances of centre-left parties in Turkey (1983-1995)

\begin{tabular}{|l|c|c|c|c|c|c|c|c|}
\hline & $\begin{array}{c}1983 \\
\text { General } \\
\text { Elections }\end{array}$ & $\begin{array}{c}1984 \\
\text { Local } \\
\text { Elections }\end{array}$ & $\begin{array}{c}1986 \\
\text { By- } \\
\text { Elections }\end{array}$ & $\begin{array}{c}1987 \\
\text { General } \\
\text { Elections }\end{array}$ & $\begin{array}{c}1989 \\
\text { Local } \\
\text { Elections }\end{array}$ & $\begin{array}{c}1991 \\
\text { General } \\
\text { Elections }\end{array}$ & $\begin{array}{c}1994 \\
\text { Local } \\
\text { Elections }\end{array}$ & $\begin{array}{c}1995 \\
\text { General } \\
\text { Elections }\end{array}$ \\
\hline HP & 30.5 & 8.8 & - & - & - & - & - & - \\
\hline SODEP & - & 23.4 & - & - & - & - & - & - \\
\hline SHP & - & - & 22.74 & 24.8 & 28.7 & 20.8 & 13.6 & - \\
\hline DSP & - & - & 8.5 & 8.5 & 9 & 10.8 & 8.8 & 14.6 \\
\hline CHP & - & - & - & - & - & 4.6 & 10.7 \\
\hline $\begin{array}{l}\text { Sum of the } \\
\text { Voting Rates }\end{array}$ & 30.5 & 32.2 & 31.24 & 33.3 & 37.7 & 31.6 & 27 & 25.3 \\
\hline
\end{tabular}

Notes: Results of all the elections were retrieved from the website of the Turkish Statistical Institute (TÜIK), except the results of the 1986 by-elections, which were achieved from http://www.resmigazete.gov.tr/arsiv/19247.pdf. Local elections' results refer to the results of the election of provincial general council members.

the DSP due to the failure of the former in fulfilling most of its economic promises while in power. Then, Alevi citizens, traditionally constituting one of the major cornerstones of the social democratic voting base, opted for putting a certain distance with the SHP -in favour of the DSP- due to its ineffectiveness during the bloody massacre of the Alevi intellectuals in Sivas in 1993 (GüneşAyata, 2002: 107).

As the CHP entered this rivalry as the third social democratic party beginning from 1992, the SHP remained much more insufficient to react effectively. Meanwhile, the sum of the votes garnered by three active social democratic parties, the SHP, the DSP, and the reborn CHP, saw a sharp decline of nearly 11 per cent from 37.7 per cent in the 1989 local elections to 27 per cent in the 1994 local elections, as shown in Table 3.

Even after the SHP-CHP merger in 1995, the ongoing waning in the electoral support of the SHP/CHP did not stop. As a result of this, in the first general elections held after the merger in 1995, the CHP was able to slightly 
exceed the national threshold by taking 10.7 per cent of the total votes. Then, in the 1999 general elections, the CHP faced a much worse scenario, and could not enter the Parliament because of failing to exceed the 10 per cent electoral threshold. In the 2002 parliamentary elections, taking advantage of the total collapse of the political centre both in the right and in the left, the CHP made a comeback to the Parliament as the main opposition party. However, as revealed by the results of the recent general elections, the party has not managed to increase its votes remarkably and seemed to be stuck in the margin of 25 per cent.

\section{The SHP in Power}

Finally, the experiment with power of the SHP will be focused as the third and final factor contributing to its failure in becoming a genuine social democratic party. In this part, the general performance of the party in the local and central power echelons will be analysed.

Reaching 28.7 per cent of the votes, the SHP unexpectedly won the 1989 local elections and acquired the municipalities of 45 cities across the country (Bila, 2008: 317). This meant that despite the indisputable predominance of the ANAP in the Assembly, the SHP obtained the power of ruling the local context in Turkey. In this regard, as repeatedly stated by İnönü, it was highly expected that the high performance of the SHP in these municipalities would pave the way for a landslide victory of the party in the upcoming 1991 general elections. In contrast to these high prospects, however, the SHP municipalities did not perform well enough to prevent the loss of the majority of the municipalities in the 1994 local elections. Needless to say, many mayors elected from the SHP ranks carried out significant tasks still remembered as the showcase of the social democratic municipality, but they were overshadowed, to a great extent, by other publicly notorious incidents for the party. As the clientele linkages fed from party loyalties dominated the policy mechanisms in the SHP municipalities, the public esteem for the party persistently faded. Moreover, the outbreak of many corruption scandals, the biggest of which being the İSKİ (İstanbul Water and Sewerage Administration) case $^{31}$, in the SHP-led municipalities not only caused a sharp decline in the popular support of the party but also boosted the political rise of the RP as a serious alternative in the local context.

Emanating from its low performance in the municipalities for two years, the SHP encountered a huge drop in its votes in the 1991 parliamentary elections and was able to rank the third among all the parties entering the Parliament.

31 The ISKI case is a publicly-known scandal exposing the corrupted activities of the Director General of ISKI, Ergun Göknel, in the granting of the key tenders. 
Despite this electoral defeat, then, the SHP, as the biggest centre-left party, succeeded in establishing a grand coalition with the DYP, the biggest centreright party, following the 1991 parliamentary elections. ${ }^{32}$ Even the formation of this coalition government meant a lot to social democrats because, after more than ten years, they would again return to power - albeit as a minor partner in the government. Furthermore, it was widely believed that this coalition experience would give the SHP the chance of making up for its mistakes in the municipalities, alongside proving itself as a credible contender for coming to power in a single-party government.

Like in municipalities, yet, the SHP fell short of being an effective coalition partner during four years in government. In spite of being established by two parties, this coalition government seemed to be under the de facto control of the DYP. The SHP, on the other hand, was publicly conceived as a 'minor' coalition partner unconditionally pursuing the DYP in the making and implementation of the government policies (Bila, 2008: 325; Kömürcü, 2010: 437). In this respect, firstly, in spite of leading the parliamentarian and societal bloc of democratisation throughout the 1980s, the SHP gradually lost the initiative in the democratisation struggle to Demirel's DYP (Bora and Erdoğan, 1999: 29). Then, after President Özal's unexpected death in 1993, the SHP, instead of coming up with its own candidate, emerged as one of the major forces backing the election of Prime Minister Demirel as the new president. Also, particularly after Tansu Çiller's ascendance to the premiership, the SHP remained ineffective in "diagnosing the predominant 'militarisation' and 'authoritarian restoration' policies applied by the state that particularly had a repercussion on the securitisation of the Kurdish issue" (Bora and Erdoğan, 1999: 29).

Even if the SHP, together with the DYP, undertook crucial legal amendments such as abolishing the legal prohibitions put on the participation of the women and the youth in politics and permitting the re-opening of the pre1980 political parties, the party was mostly unable to fulfil its hitherto upheld socio-economic promises. In particular, declaration of the 5 April 1994

32 After the CHP-Justice Party (Adalet Partisi - AP) government established under the premiership of İsmet İnönü's in 1961, the DYP-SHP coalition marked the second grand coalition in the Turkish political history. 
Measures ${ }^{33}$, reminding the infamous 24 January 1980 Decisions $^{34}$ due to its content, by a government comprising the SHP caused a huge reaction particularly among the working class and the urban poor, the backbone of the SHP's electoral support, against the party. As the 'bitter recipe' generated out of these measures put most of the burden of the economic crisis on the shoulders of these masses, the SHP saw a drastic decline in its popularity.

In a nutshell, the period the SHP passed in power added up to the loss of its credibility and plausibility in the public opinion. Yet, more importantly, these incidents kept exerting a negative impact on the public image of the CHP and accounted for part of the seen and unseen barriers put on the way of its taking office again.

\section{Conclusion}

Entering the political life under extremely harsh circumstances of the post1980 coup period, the SHP ultimately proved incapable of evolving into a 'genuine' social democratic party, as it repeatedly put for itself as the ultimate target, due to failing to resist three primary challenges discussed, and ended up merging with the CHP in 1995. However, this stated failure of the SHP did not disappear all of a sudden and, more importantly, kept overshadowing the CHP in the form of historical baggage.

Beginning from the late-1980s, in the radically changing political environment of international and domestic politics, identified with the prevalence

33 The 5th April Measures comprised several measures intending to re-balance current accounts deficit, decrease public expenditures, and create extra revenue via privatizing many state economic enterprises. In the press conference, held on 5 April 1994, Prime Minister Tansu Çiller, accompanied by the SHP leader Murat Karayalçın, promised a more prosperous and secure future for ordinary citizens while declaring these measures. Nevertheless, at the end of the implementation of this stabilization package, there occurred rising unemployment and deepening income injustice.

34 The 24th January Decisions, as popularly known, refer to the economic stabilization measures taken by the minority government of Süleyman Demirel against the escalating economic crisis in Turkey. Shaped by Turgut Özal, as the Undersecretary of Prime Ministry, and declared by Prime Minister Demirel on 24 January 1980, these decisions aggressively aimed at integrating Turkish economy with the global capitalist system and institutionalizing market economy in Turkey. In accordance with this aim, many radical neoliberal measures, such as liberalizing the foreign trade, containing public expenditures and agricultural subsidies, abandoning the import substitution industrialization (ISI) model in favour of the export-oriented growth strategy were taken. Right after the 1980 coup, the military government, in which Turgut Özal served as the Deputy Prime Minister, kept practising these measures. 
of New Right-oriented neoliberal prescriptions for political and socio-economic problems, the SHP found itself in a rather weak position. Although it endeavoured to adjust to those changing conditions in order to get over the mounting challenges, the SHP could achieve partial success like other centreleaning parties in Turkey.

The intra-party turmoil of the SHP, comprising its organisational crisis, ideological fluctuations, and declining electoral support, came to mean a broader structural/conjunctural stalemate for the party. Regarding the organizational crisis, the SHP was severely pressurised, in the short run, both by the legal restrictions of the military regime put against the organisational advance of the post-1983 political parties and by the antidemocratic provisions of the new Constitution, Political Parties Law and the Election Law. Then, in the long run, the SHP much more engaged with the persistent clashes with rival social democratic parties that wreaked havoc on its organisational strength. Moreover, the patron-client bonds surrounding the organisational networks of the party shifted its organisational focus from the ideological/political matters to the more material or daily ones. In the face of all these challenges, it became much more difficult for the SHP to preserve its organisational unity.

In terms of its core ideological stance, the SHP became subject to ideological drifts more, parallel to the mix of external and internal factors. Focusing on the target of running the country, the SHP happened to leave aside its prior emphasis on the social democratic ideology for the sake of a more pragmatist approach. Ironically, the more power-centric the party became, the further it distanced from the possibility of governing again due to the blurring lines of its social democratic identity, erasing the differences it once had with the centre-right parties to a greater extent. Put differently, although the SHP attempted to be the 'party of everyone' representing the interests of each political, socio-economic, cultural and regional group, it turned out to be 'the party of none' (Kozanoğlu, 1992: 40). At the end of the day, the SHP stood as a political party having profound problems with its core ideological standpoint.

Getting influenced by, and in turn influencing, these two sub-factors, the conventional voting ground of the party much more headed towards either rival social democratic parties or radical right-wing alternatives, as proven by the declining electoral performance of the party especially in the aftermath of the 1989 local elections.

Finally, the SHP's period in office can be counted as one of the main factors deepening the failure of the party. In this respect, in direct contrast to the high expectations held by the party officials, the years the SHP passed in municipalities and in the DYP-SHP coalition did not benefit the party; on the contrary, prepared for the consuming of its political credibility. 
Inevitably, the failure of the SHP had a lasting impact on the later course of social democratic ideology in Turkey. In particular, the poor performance in power and rising ideological ambivalences of the SHP have lied beneath the successive electoral defeats and ongoing attempts for finding a new ideological stake of the CHP, as one of the leading factors. As is the case, it would not be exaggerating to argue that a great deal of the problems plaguing the social democratic ideology, and definitely the CHP, for a while are likely to be traced back to the SHP phase.

Last but not least, despite all its problematic aspects, the SHP experiment harbours a highly valuable historical reservoir, alongside many opportunities. At the very least, this period reveals that should the sound strategies be adopted in tune with the social democratic approach, there is no reason for a social democratic party not to score another election victory in Turkey, similar to the one in 1989. Looking from another perspective, yet, it is also possible to coincide with flawed political decisions and wrongly calculated steps in the SHP period. Even these two points are sufficient to notice that the SHP experiment stands not merely as a simple historical 'parenthesis' but one of the major cornerstones of the history of social democracy in Turkey. Given the quest for a social democratic revival still goes on within the CHP, readdressing the 'SHP years' gains much more significance, particularly for the ones in pursuit of a sound social democratic understanding responsive to the needs and pressing issues of the present.

\section{References}

Ayata, Sencer and Ayşe Güneş-Ayata (2007), "The Center-Left Parties in Turkey", Turkish Studies, 8 (2): 211-232.

Baykal, Deniz (1991), Yeni Yaklaşımlar, Yeni Hedefler (İstanbul: Filiz Yayıncılık).

Baykal, Deniz and İsmail Cem (1992), Yeni Sol (İstanbul: Cem Yayınevi).

Bila, Hikmet (2008), CHP (1919-2009) (İstanbul: Doğan Kitap).

Bora, Tanıl and Necmi Erdoğan (1999), “CHP ve DSP'de Solun Bakiyesi Nedir?”, Birikim, 120: 2835.

Bora, Tanıl (2007), "SODEP'i ve Eski-SHP'yi Rahmetle Anarken”, http://www.birikimdergisi.com/ guncel-yazilar/159/sodep-i-ve-eski-shp-yi-rahmetle-anarken (20.09.2017).

Cem, İsmail (1998), Sosyal Demokrasi Nedir, Ne Değildir? (İstanbul: Can Yayınları)

Cıngı, Aydın (2011), "CHP: A Party on the Road to Social Democracy", International Policy Analysis Paper, Friedrich Ebert Stiftung. 
Emre, Yunus (2015), "Why has Social Democracy not Developed in Turkey? Analysis of an Atypical Case", Journal of Balkan and Near Eastern Studies, 17 (4): 392-407.

Erdoğan, Necmi (1992), “Türk Sosyal Demokrasisinin Hal-i Pür Melali”, Birikim, 33: 32-36.

Ergüder, Ü. (1991), “The Motherland Party, 1983-1989", Heper, Metin and Jacob Landau (Ed.), Political Parties and Democracy in Turkey (London: I.B. Tauris): 152-169.

Esen, Berk (2005), "Social Democratic Populist Party and the Transformation of the Turkish Left: An Unfinished Dream", Unpublished MA Thesis (İstanbul: Sabancı University).

Güneş-Ayata, Ayşe (1993), "Ideology, Social Bases, and Organization Structure of the Post-1980 Political Parties", Eralp, Atilla and Birol Yeşilada (Ed.), Political and Socioeconomic Transformation of Turkey (London: Praeger): 31-49.

Güneş-Ayata, Ayşe (1995), "Türkiye'nin Demokratikleşme Sürecinde Ortanın Solu Hareketi”, Ankara Üniversitesi Siyasal Bilgiler Fakültesi Dergisi, 50 (3): 79-88.

Güneş-Ayata, Ayşe (2002), “The Republican People's Party”, Turkish Studies, 3 (1): 102-121.

Hakan, Ahmet (2001), Deniz Baykal, CHP ve Anadolu Solu (İstanbul: Birey Yayıncılık).

Kalaycıoğlu, Ersin (2002), "The Motherland Party: The Challenge of Institutionalization in a Charismatic Leader Party", Rubin, Barry and Metin Heper (Ed.), Political Parties in Turkey (London: Frank Cass and Company): 41-61.

Karakök, Tunay (2011), “Menderes Dönemi'nde (1950-1960) Türkiye'de Eğitim”, Yükseköğretim ve Bilim Dergisi, 1 (2): 89-97.

Karnitschnig, Matthew (2018), "Who Killed European Social Democracy?", https://www.politico.eu/ article/matteo-renzi-martin-schulz-italy-germany-who-killed-european-social-democracy/ (13.08.2018)

Keyman, E. Fuat and Ziya Öniş (2007), "Globalization and Social Democracy in the European Periphery: Paradoxes of the Turkish Experience", Globalizations, 4 (2): 211-228.

Kiriş, Hakan M. (2012), "The CHP: From the Single Party to the Permanent Main Opposition Party", Turkish Studies, 13 (3): 397-413.

Kozanoğlu, Can (1992), "Şimdi SHP'ye Hakaret 'In'”, Birikim, 33: 37-41.

Kömürcü, Derya (2009), "Geçmişle Gelecek Arasında Bir Alternatif Arayışı: Sosyal Demokrat Halkçı Parti”, Yakın Doğu Üniversitesi Sosyal Bilimler Dergisi, 2 (2): 2-31.

Kömürcü, Derya (2010), Türkiye'de Sosyal Demokrasi Arayışı (SODEP ve SHP Deneyimleri) (İstanbul: Agora).

Mango, Andrew (1991), "The Social Democratic Populist Party, 1983-1989", Heper, Metin and Jacob Landau (Ed.), Political Parties and Democracy in Turkey (London: I.B. Tauris): 170-187.

Sassoon, Donald (2010), One Hundred Years of Socialism: The West European Left in the Twentieth Century, (London: I.B. Tauris).

SHP (1985), Parti Programı (Ankara).

SHP (1987), Seçim Bildirgesi (Ankara).

SHP (1989), SHP Genel Sekreteri Deniz Baykal'ın 'Sosyal Demokrasi'de Ekonomi Politikaları' Konulu Uluslararası Konferansta Yaptığı Konuşma (Ankara).

SHP (1990), Sosyaldemokrat Halkçı Parti'nin Doğu ve Güneydoğu Sorunlarına Bakışı ve Çözüm Önerileri, SHP Merkez Yürütme Kurulu (Ankara).

SHP (1991a), Seçim Bildirgesi: Yeni Bir Türkiye Için Illk Hedefler (Ankara). 
SHP (1991b), Ekonomide Onarım ve Atılım Programı (Ankara).

SHP (n.d.), SHP Genel Sekreteri Deniz Baykal'ın Cumhurbaşkanı Seçimi ve Türk Sanayinin Durumuna İlişkin Görüşleri (Ankara).

Tachau, Frank (1991), “The Republican People's Party, 1945-1980”, Heper, Metin and Jacob Landau (Ed.), Political Parties and Democracy in Turkey (London: I.B. Tauris): 99-117.

TÜiK (n.d.), Milletvekili Seçim İstatistikleri, http://www.turkstat.gov.tr/VeriBilgi.do?alt_id=1061 (01.10.2017).

Turan, IIter (2006), "Old Soldiers Never Die: The Republican People's Party of Turkey", South European Society and Politics, 11 (3): 559-578. 